\title{
THE DETERIORATION RESULTING FROM BURIAL ENVIRONMENT ON ARCHAEOLOGICAL GLASS: COMPARATIVE STUDY
}

\author{
Rasha T. HAMAD \\ Conservation Department, Faculty of Archaeology, Fayoum University \\ E-mail: rta00@,fayoum.edu.eg
}

\begin{abstract}
The aim of this research is to study the deterioration resulting from burial context on archaeological glass. Investigations were performed on a series of Islamic glass fragments coming from different excavation sites (Deir ElGhannam and Deir El-Banat) in Fayoum which was a major manufacturing place for archaeological glass during Islamic periods. The mineralogical and elemental compositions of glass fragments and soil were determined by Energy dispersive X-ray (EDX) methods, while glass fragments' surfaces were examined by Scanning Electron Microscope (SEM) and USB Digital Microscope. Deterioration aspects resulting from being buried varied among excavations in the Fayoum, according to chemical composition and soil moisture's proportion which increase in Deir El-Ghannam and decrease in Deir El-Banat. The study shows that different kinds of salts "Chloride and Sulphate", dirty layers, soil deposits affect the thickness and colour of glass, on top of glass corrosion layers. This study resulted in the conception of a methodology to treat the deterioration aspects.
\end{abstract}

\section{KEYWORDS}

Deterioration, Burial environment, Excavation, Deir ElBanat, Deir El-Ghannam

\section{INTRODUCTION}

Fayoum was a major place for manufacturing archaeological glass during Islamic periods. Despite that this production has not been comprehensively examined. By focusing on the material coming from the excavations of two monasteries, this study aims to identify and analyse the chemical composition, soil moisture content, and other soil properties to

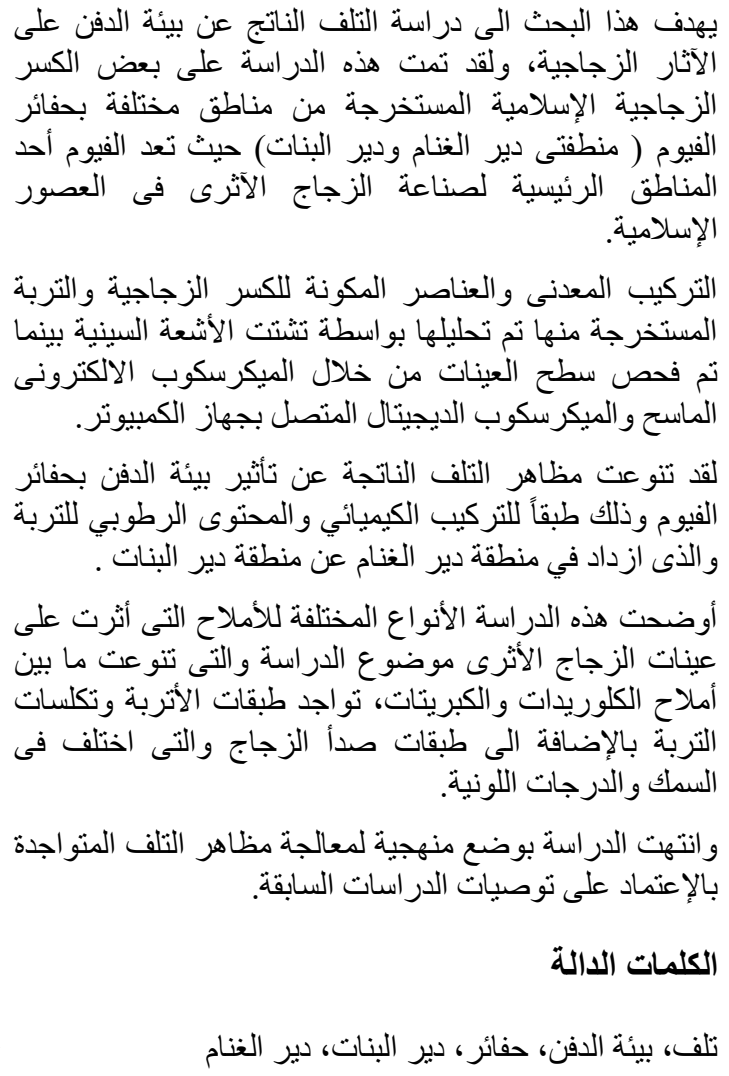


determine the impact of burial environment on glass fragments from the sites of Deir ElGhannam and Deir El-Banat in Fayoum.

The monastery of Deir El-Ghannam is located between the monasteries of Gabriel and of St. Anba Abram in Azab, Fayoum, while Deir El-Banat is about one kilometre northeast from the monastery Gabriel. There are excavations belonging to the Antiquities Authority. ${ }^{1}$

Glass is a comparatively durable material when buried. ${ }^{2}$ The degradation of buried glass depends on water corrosion. The leaching of the components of glass and an ion exchange reaction between the glass and the soil are accompanied by the migration of water into the alteration layer. In addition, corroding products on the surface may contain water within their crystalline structure. ${ }^{3}$

However, corroded glass surface occurs in wet soils and moist leading to a transparency loss and the formation of a surface crust rich in silica but exhausted of its basic ions. The glass is weakened by this process which may accelerate the shattering of thinner objects. ${ }^{4}$

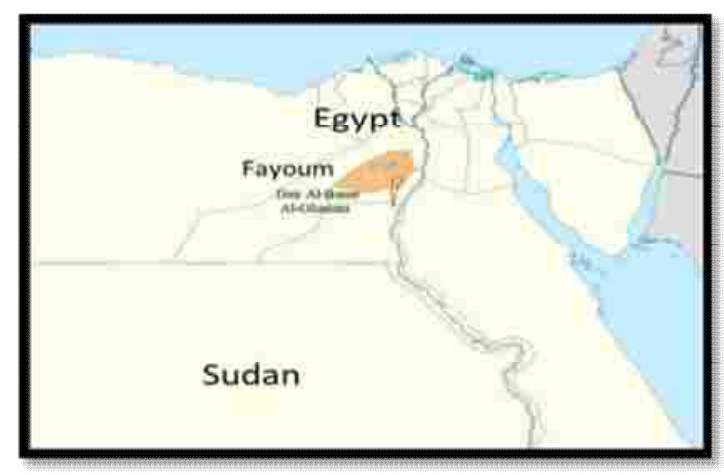

Figure 1 Location of Deir El-Ghannam and Deir El-Banat

The surface degradation rate in soil is affected by the composition of glass and not easily expected. ${ }^{5}$ The alkali content and type are critical. In general ancient glass is more resistant to chemical attacks than the medieval one as wood ash containing potassium (K) started replacing soda ash in its manufacture. Under moderately alkaline and acidic conditions ( $\mathrm{pHb} 9$ ), alkali ions are leached from the glass matrix; under more alkaline conditions, hydroxyl ions disrupt silicon-oxygen bonds within the structure of the silica. ${ }^{6}$

Layers of laminar surface are easily formed in situations of higher $\mathrm{PH}$ alkaline; ${ }^{7}$ these layers may be iridescent. In the driest soils, coatings of surface and other decoration on glass are expected to decompose very rapidly beyond 100 year (b100 y). The strong dependence of glass corrosion rates on manufacture and material composition leads to

\footnotetext{
${ }^{1}$ Andraos, "Coptic History", p. 59.

2 Jackson et al.," "An assessment of compositional”, pp. 489-507.

${ }^{3}$ Roemich et al., “Archaeological Glass”. pp 137-149

${ }^{4}$ Huisman et al., "Degradation processes", pp 398-411.

${ }^{5}$ Van Giffen et al., "Weathered Archaeological Glass"

${ }^{6}$ Melcher et al., "Degradation of glass artifacts", pp. 916-926.

${ }^{7}$ Roemich et al., "Results from burial experiments", pp. 97-108.
}

- 226 - The Deterioration Resulting from Burial Environment on Archaeological Glass 
doubt any expectation of degradation of the surface relative to the different kinds of soil. In arid soils, corrosion is less expected; soils which are highly alkaline, are the most corrosive.

While glass is well preserved in soil, it tends to shatter and the resulting shards may be dispersed. Physical damage to glass buried in soil can be due from static and dynamic forces. Static forces increase from the treading action of people, animals and vehicle movements may propagate in the subsoil. ${ }^{8}$ In soils where clay minerals are present, these will potentially create destructive mechanical forces during wetting-drying cycles. Soil stiffness, which is a measure of resistance to deformation, will affect the likelihood that brittle objects will be fractured. For instance, a dry clay soil will be more resistant to deformation and better protect objects from shattering than a wet sandy soil. However, within most soils, glass is highly resistant to degradation and will be well preserved. The exception lies in damp and strongly alkaline soils. ${ }^{9}$

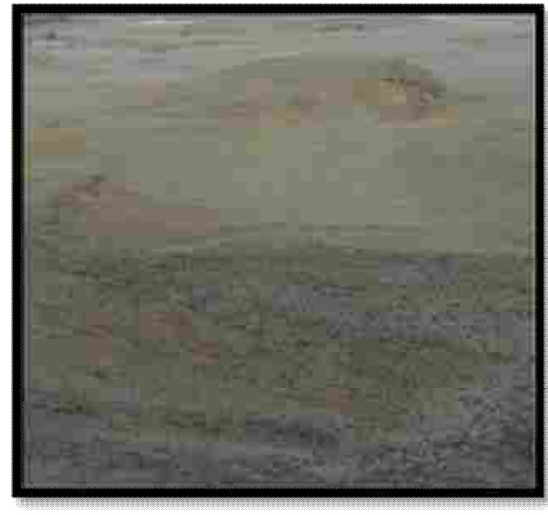

Figure 2 A View of Deir El-Ghannam excavations; Provenance of Samples A \& B

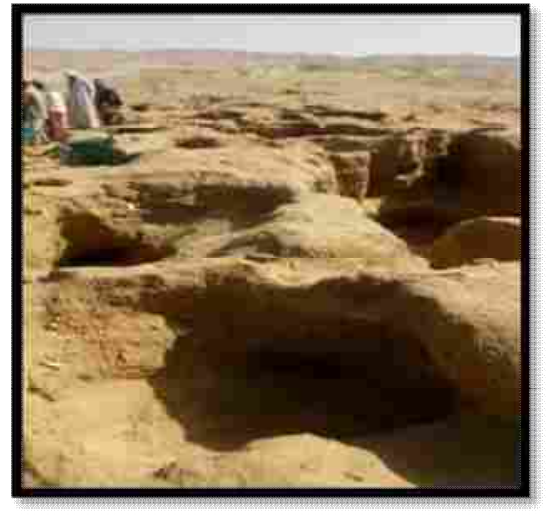

Figure 3 A View of Deir El-Banat excavations; Provenance of Samples C \& D

Glass and weathering crusts become obscured through insoluble salts' encrustations. These are prevalent where the excess lime in glass is leached out, to be deposited as a whitish deposit on the surface or within the decayed layers of glass. ${ }^{10}$

\section{MATERIALS AND METHODS}

\subsection{Samples}

\subsubsection{Glass Samples}

Two glass samples were selected from both sites of Deir El-Banat and Deir El-Ghannam, the excavation sites of which are shown in Figures 2 and 3. Figures 4 and 5 display the examination of the glass samples.

\subsubsection{Soil Samples}

Two samples from burial environment "one from each site".

Figures 7 and 8 shows an analysis of the soil samples from Deir El-Banat and Deir ElGhannam.

\footnotetext{
${ }^{8}$ Dain-Owens et al., "The risk of harm to archaeological artefacts", pp. 1175-1186

${ }^{9}$ Mark et al., "Predicting the preservation of cultural artefacts" pp. 249-263.

${ }^{10}$ Cronyn, "The Elements of Archaeological Conservation"
} 


\subsection{USB Digital Microscope}

The glass samples were examined by Leuchtturm USB Digital Microscope (China) with 20 to 500x zoom, 8 LED lights with Measurement Software.

\subsection{SEM- EDX}

Scanning Electron Microscope (SEM) images of the glass samples were taken using a Jeol (Tokyo, Japan) JSM 5600 LV equipped with an Oxford Instruments 6587 EDX microanalysis detector. The images were taken under low vacuum conditions where samples did not show any charging effects. Energy Dispersive X-ray microanalysis (EDX) was used to obtain information on the elemental composition of the excavation soil and glass samples.

\subsection{Soil Moisture Content (oven-drying method)}

Samples of soil from both areas were taken to calculate the moisture content (Table 1) according to the following equation:

Wet soil weight $=\mathrm{W} 2-\mathrm{W} 3$

Dry soil weight $=\mathrm{W} 3-\mathrm{W} 1$

The percentage of the wet $/$ dry soil $=\mathrm{W} . \mathrm{C} \%=(\mathrm{W} 2-\mathrm{W} 3) /(\mathrm{W} 3-\mathrm{W} 1) \times 100$

Where: W1 is "weight of empty container", W2 is "Container + wet soil", and W3 is "Container + dry soil".

The dry soil was obtained by being exposed to an oven at $105^{\circ} \mathrm{C}$ for $24 \mathrm{~h}$.

\section{RESULTS}

\subsection{USB Digital Microscope Examination}

The examination by USB Digital Microscope for Deir El-Ghannam samples A\& B shows glass corrosion layers, glass dulling and iridescence (Figure 4).
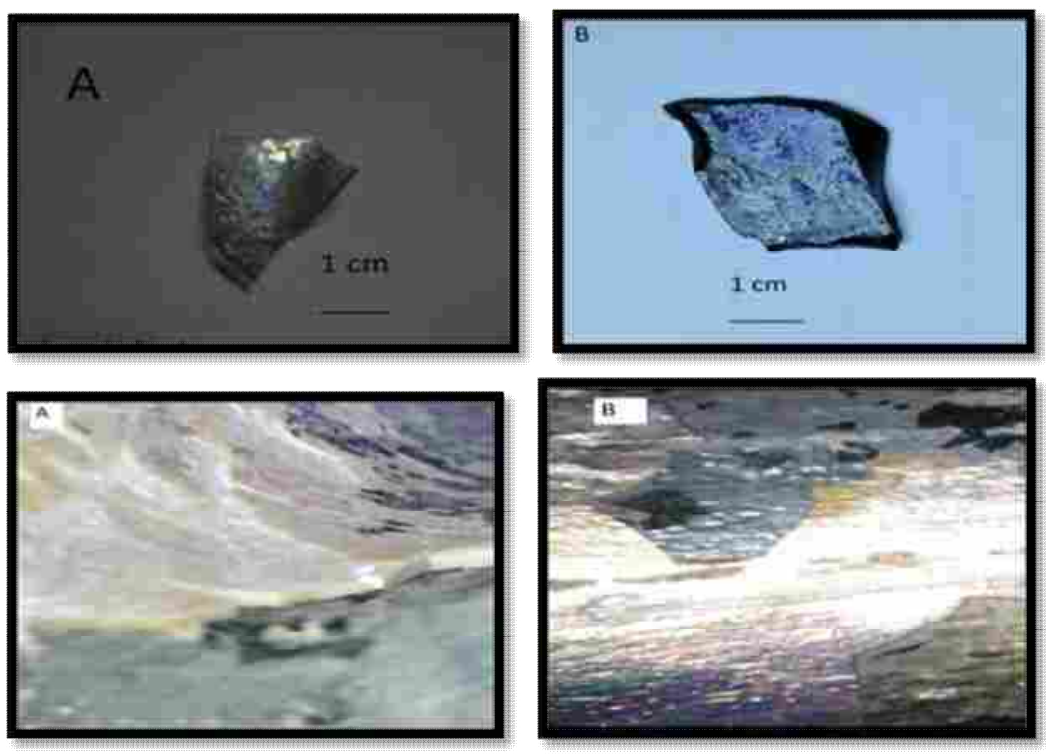

Figure 4 USB Digital Microscope photos for Samples A and B from Deir El-Ghannam

- 228 - The Deterioration Resulting from Burial Environment on Archaeological Glass 
The photographs done by USB Digital Microscope on the Samples C and D from Deir-ElBanat excavation show soil deposits, dirty layers, salt crystals, brown spots, and air bubbles inside the glass material (Figure 5).
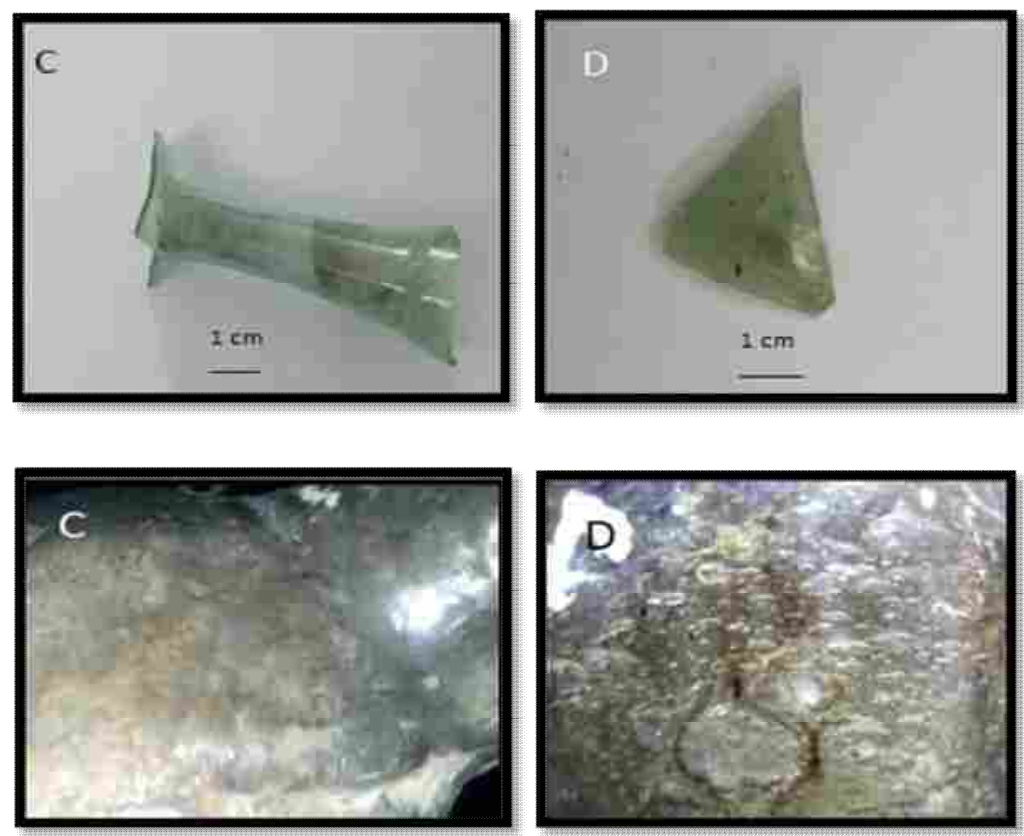

Figure 5 USB Digital Microscope photos for Samples C and D from Deir-El-Banat excavation

\subsection{SEM- EDX}

The examination by SEM clearly shows glass corrosion, gaps, cracks and salt crystals in Deir El-Ghannam.

SEM photos of Samples A and B from Deir El-Ghannam display glass corrosion layers, salt crystals and gaps (Figure 6).
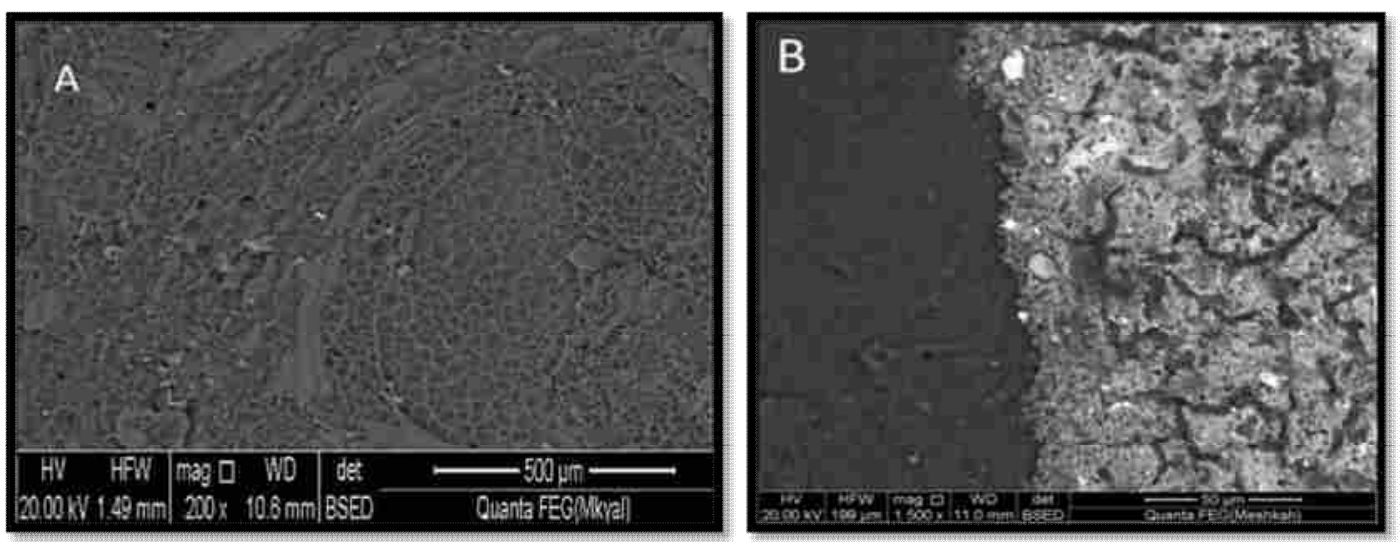

Figure 6 SEM photos for Samples A and B and D from Deir El-Ghannam excavation 
The results of EDX microanalysis indicate that the components of the corroded glass Sample A of Deir El-Ghannam excavations show the following major components: Silica $\left(\mathrm{SiO}_{2} 71.13 \%\right)$, Soda $\left(\mathrm{Na}_{2} \mathrm{O} 7.85 \%\right)$, Potash $\left(\mathrm{K}_{2} \mathrm{O} 138 \%\right)$, Lime (CaO 11.88\%), Alumina $\left(\mathrm{Al}_{2} \mathrm{O}_{3} 4.69 \%\right)$ and a small percentage of Chlorine $\left(\mathrm{Cl}_{2} \mathrm{O} 1.67 \%\right)$ (Figure 7).

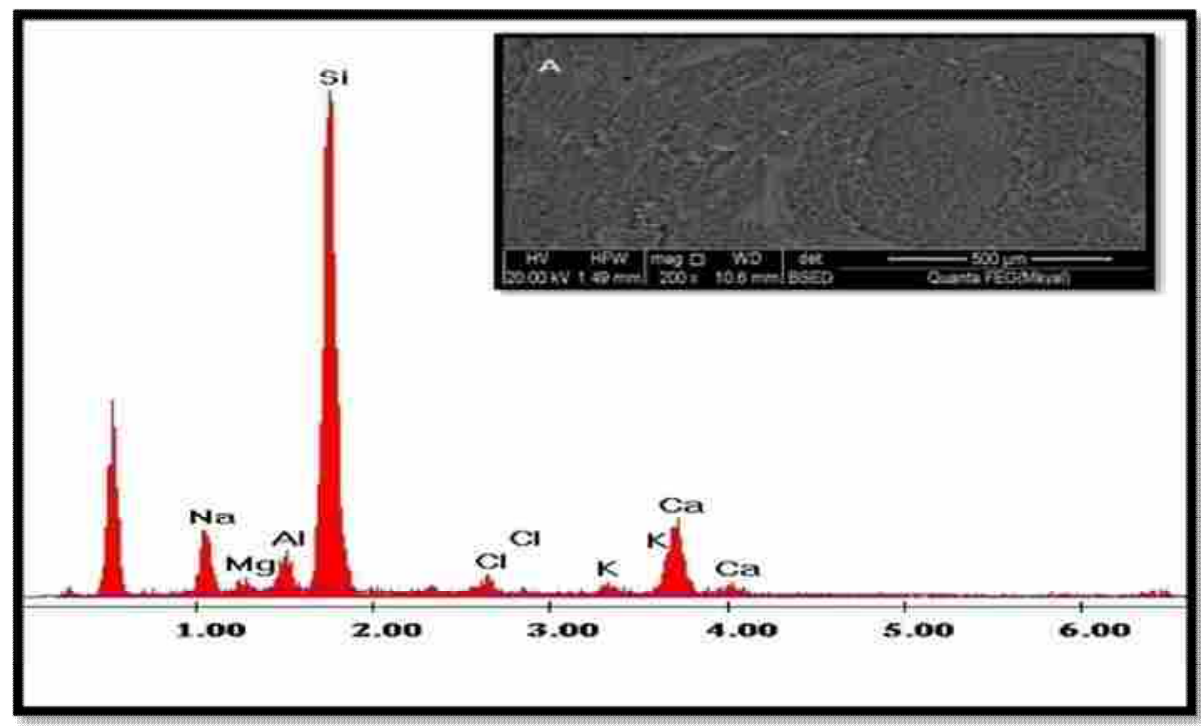

Figure 7 The components of Sample A from Deir El-Ghannam excavation by EDX

The EDX of Sample B corroded glass (Figure 8) indicates that the major components are: Silica ( $\mathrm{SiO} 2$ 71.73\%), Soda (Na2O 2.62\%), Potash (K2O 1.24\%), Lime (CaO 6.36\%), Alumina (Al2O3 7.77\%), Chlorine $\left(\mathrm{Cl}_{2} \mathrm{O}\right.$ 1.90\%), Magnesium oxide ( $\left.\mathrm{MgO} 2.53 \%\right)$ and finally Iron oxide $\left(\mathrm{Fe}_{2} \mathrm{O}_{3} 5.84 \%\right)$.

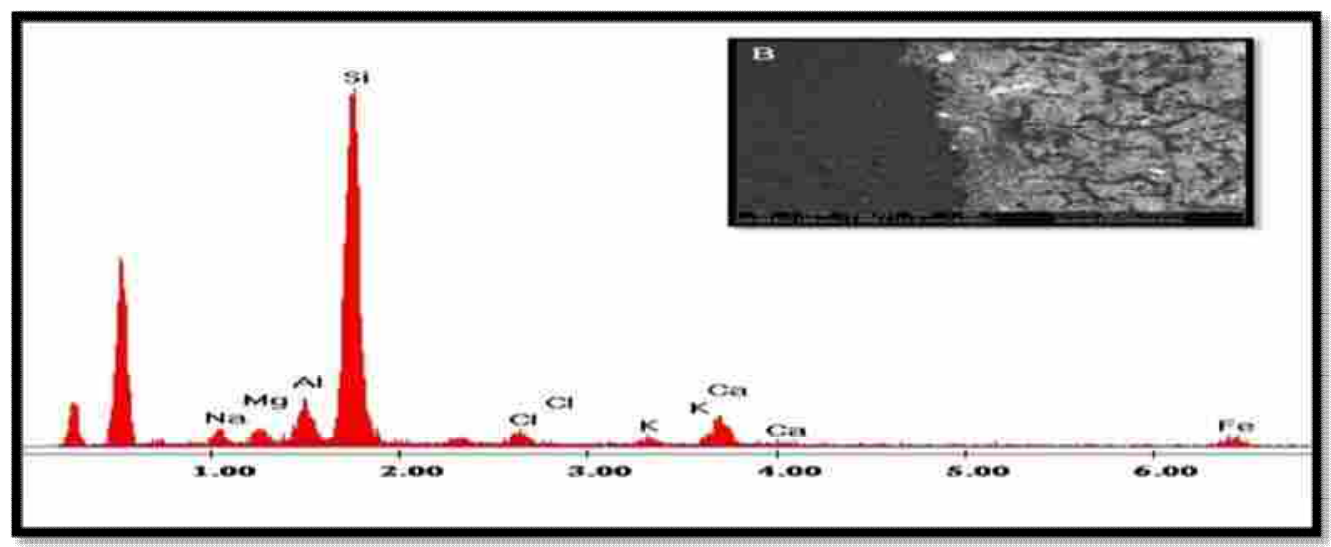

Figure 8 The components of Sample B from Deir El-Ghannam excavation by EDX

Samples C and D from Deir El-Banat are in good condition. SEM shows dirty layers and soil deposits (Figure 9).

- 230 - The Deterioration Resulting from Burial Environment on Archaeological Glass 

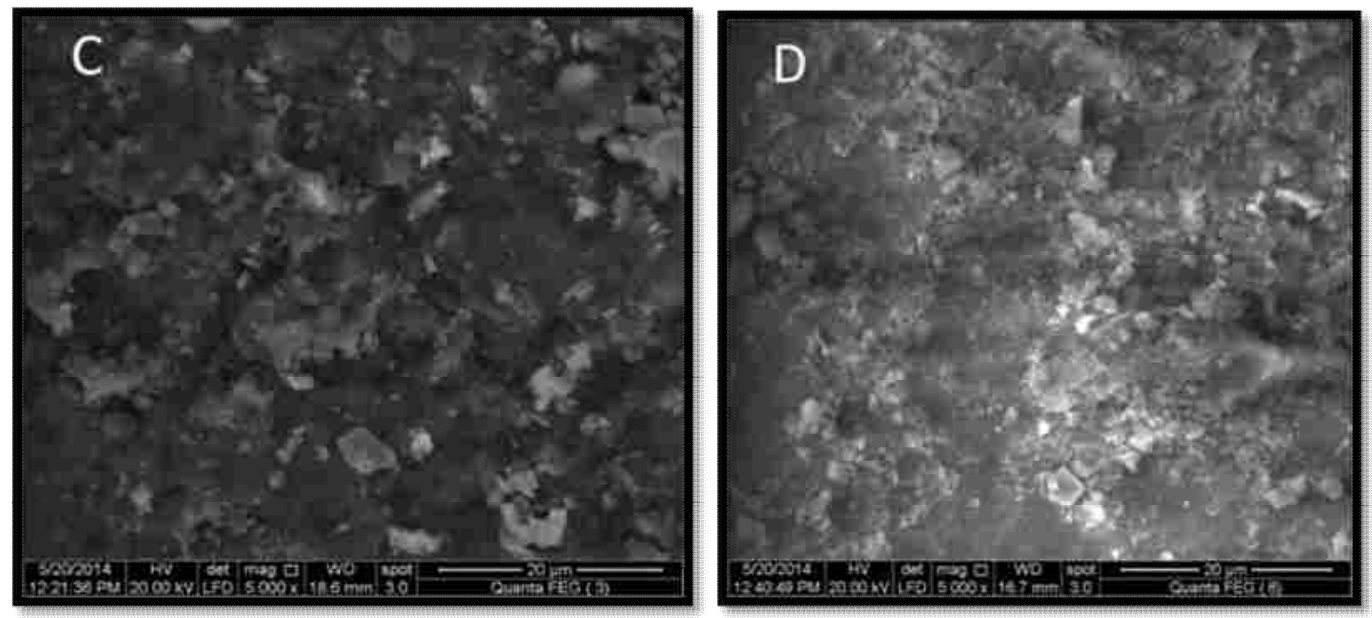

Figure 9 SEM photos for Samples C and D from Deir El-Banat excavation

The EDX Microanalysis for Sample $\mathrm{C}$ from Deir-El-Banat shows the following components: Silica $\left(\mathrm{SiO}_{2} 65.62 \%\right)$, Soda $\left(\mathrm{Na}_{2} \mathrm{O} 5.33 \%\right)$, Potash $\left(\mathrm{K}_{2} \mathrm{O} 2.41 \%\right)$ Lime $(\mathrm{CaO}$ $12.18 \%$ ), Alumina $\left(\mathrm{Al}_{2} \mathrm{O}_{3} 8.27 \%\right)$, Chlorine $\left(\mathrm{Cl}_{2} \mathrm{O} 2.28 \%\right)$, Magnesium oxide $(\mathrm{MgO}$ $2.24 \%$ ), and Iron oxide $\left(\mathrm{Fe}_{2} \mathrm{O}_{3} 5.23 \%\right)$ (Figure 10).

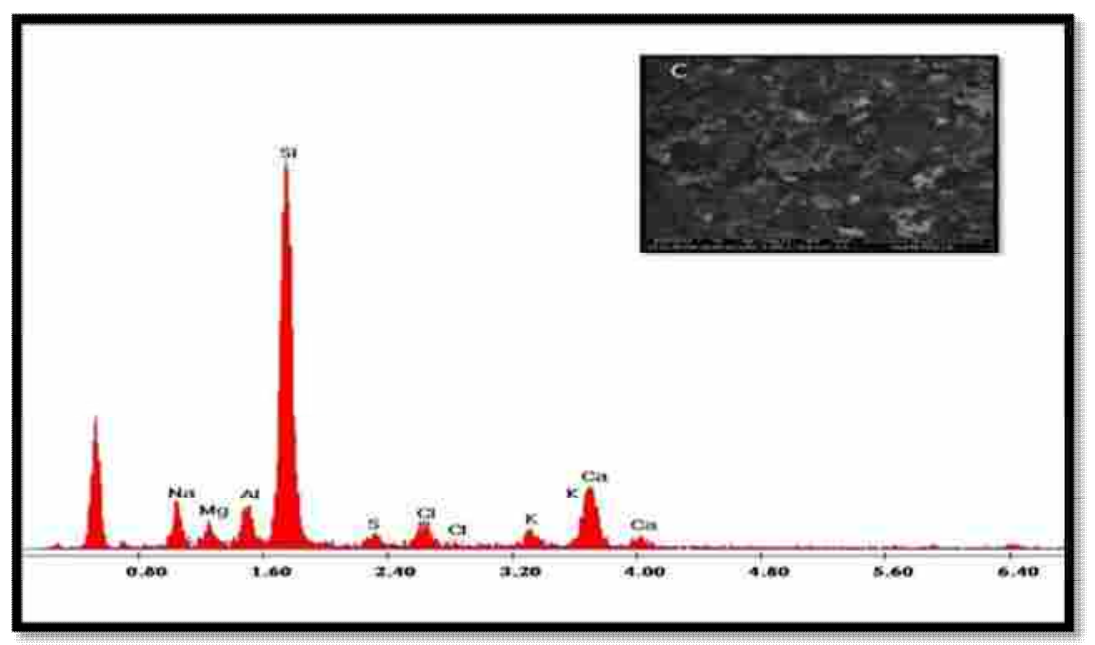

Figure 10 The components of Sample C from Deir El-Banat excavation by EDX

Glass sample D indicates that the major components are: Silica $\left(\mathrm{SiO}_{2} 66.63 \%\right)$, Soda $\left(\mathrm{Na}_{2} \mathrm{O} 1.88 \%\right)$, Potash $\left(\mathrm{K}_{2} \mathrm{O} 2.28 \%\right)$, Lime $\left(\mathrm{CaO}\right.$ 9.23\%), Alumina $\left(\mathrm{Al}_{2} \mathrm{O}_{3} 5.69 \%\right)$, Chlorine $\left(\mathrm{Cl}_{2} \mathrm{O}\right.$ 3.12\%), Magnesia ( $\mathrm{MgO} 2.41 \%$ ), and Sulphur trioxide ( $\mathrm{So}_{3} 3.24 \%$ ) (Figure 11). 


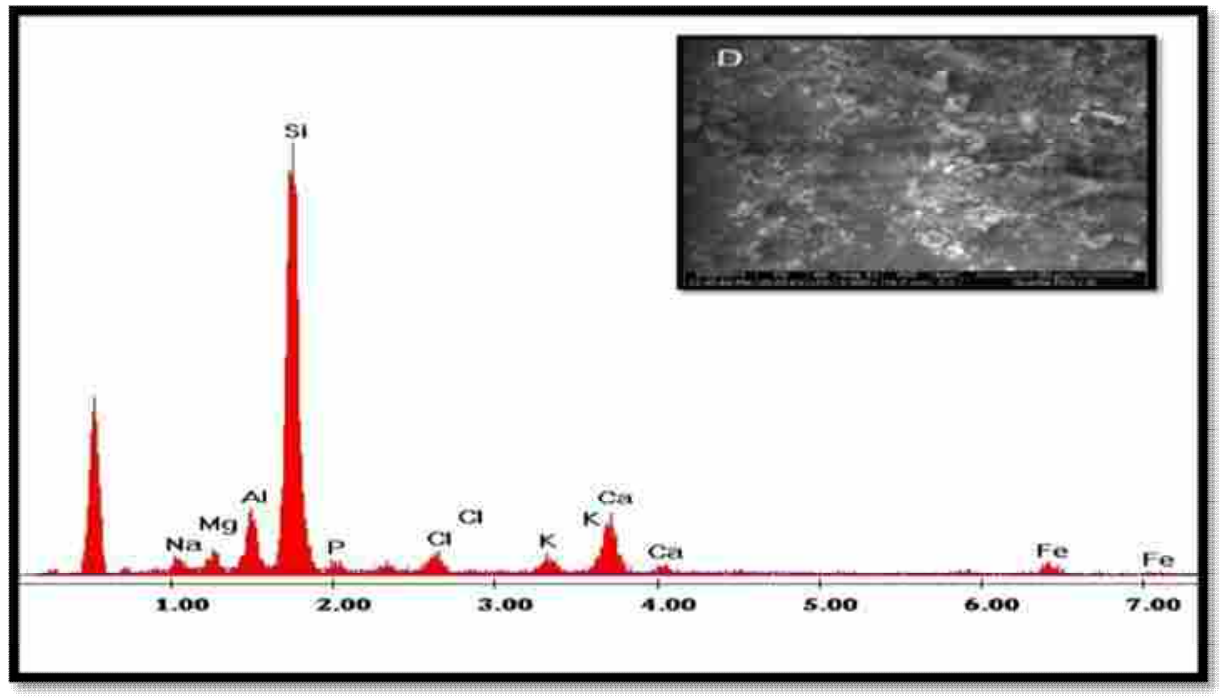

Figure 11 EDX of Sample D from Deir El-Banat excavation

\subsection{Soil analysis}

\subsubsection{EDX}

The results of EDX Microanalysis indicate that the components of the soil sample of Deir El-Ghannam are: Silica $\left(\mathrm{SiO}_{2} \sim 49.95 \%\right)$, Lime $(\mathrm{CaO} \sim 12.50 \%)$, Alumina $\left(\mathrm{Al}_{2} \mathrm{O}_{3} \sim\right.$ $13.18 \%)$, Magnesium Oxide $(\mathrm{MgO} \sim 2.77 \%)$, Soda $\left(\mathrm{Na}_{2} \mathrm{O} \sim 3.77 \%\right)$, Potash $\left(\mathrm{K}_{2} \mathrm{O} \sim\right.$ $1.46 \%)$, Chlorine $\left(\mathrm{Cl}_{2} \mathrm{O} \sim 2.67 \%\right)$, Iron Oxide $\left(\mathrm{Fe}_{2} \mathrm{O} 3 \sim 9.25 \%\right)$, and finally Sulphur trioxide (So3 3.03\%) (Figure 12).

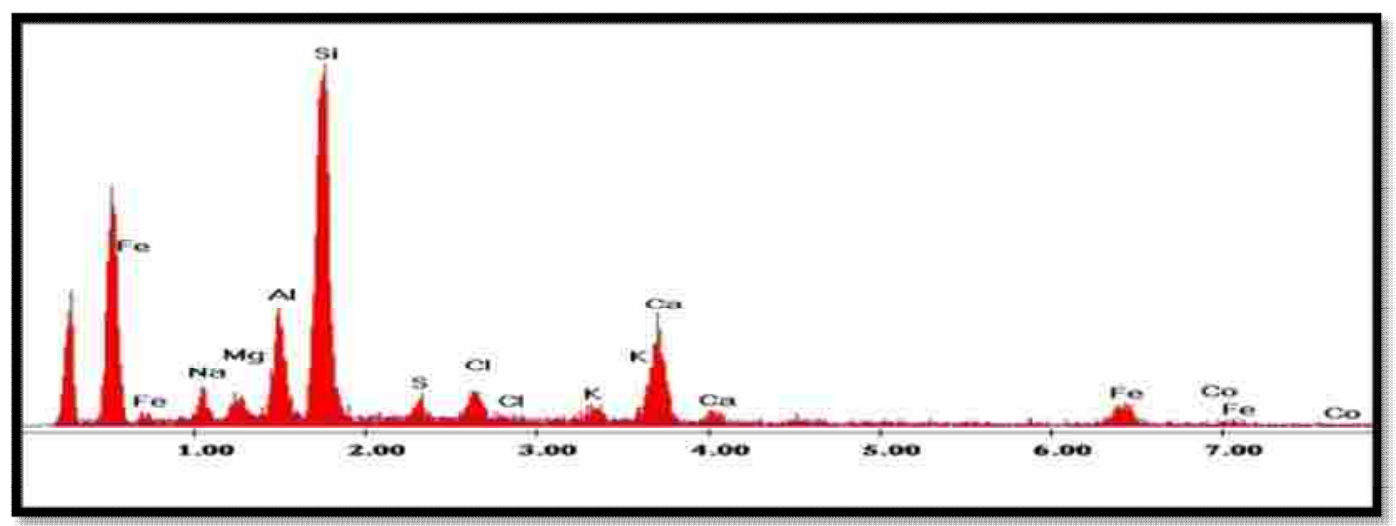

Figure 12 EDX of Deir El-Ghannam soil

The components of the sample of soil from Deir El-Banat are: Silica $\left(\mathrm{SiO}_{2} \sim 62.57 \%\right)$, Lime ( $\mathrm{CaO} \sim 8.05 \%)$, Soda $\left(\mathrm{Na}_{2} \mathrm{O} \sim 2.44 \%\right)$, Alumina $\left(\mathrm{Al}_{2} \mathrm{O}_{3} \sim 4.13 \%\right)$, Potash $\left(\mathrm{K}_{2} \mathrm{O} \sim\right.$ $2.60 \%)$, Chlorine $\left(\mathrm{Cl}_{2} \mathrm{O} \sim 1.96 \%\right)$, Carbon oxide $\left(\mathrm{Co}_{2} \sim 14.32 \%\right)$, and Sulphur trioxide $\left(\mathrm{So}_{3} 3.91 \%\right.$ ) (Figure 13).

- 232 - The Deterioration Resulting from Burial Environment on Archaeological Glass 


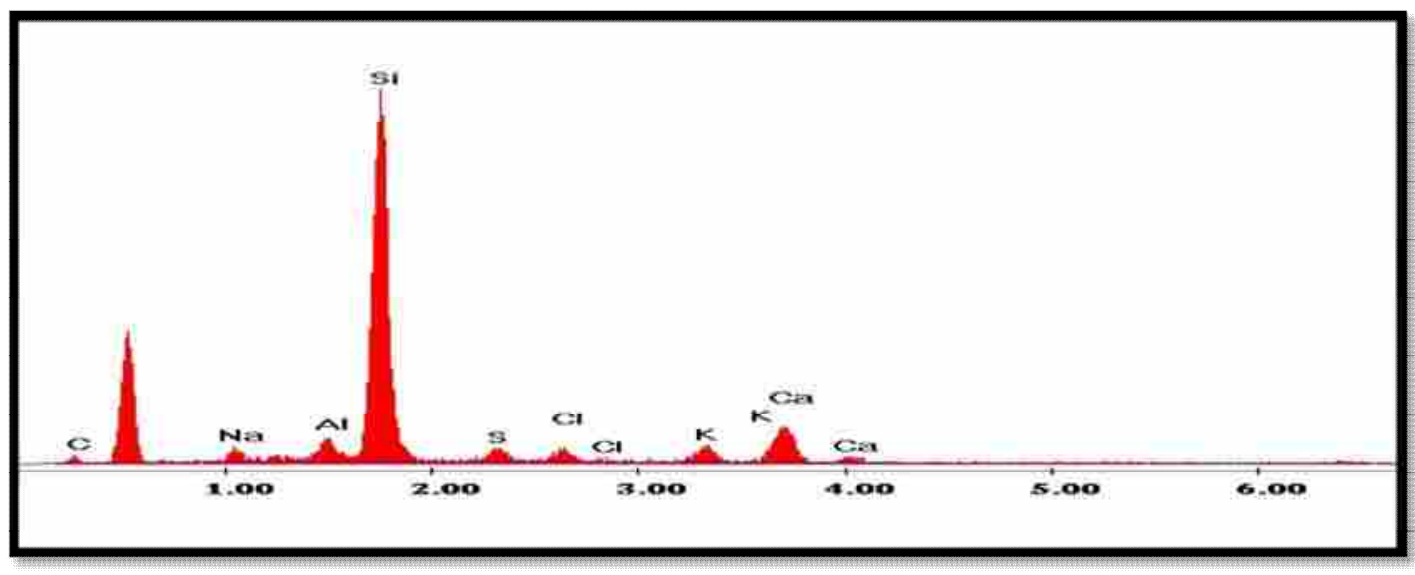

Figure 13 EDX of Deir El-Banat soil sample

\subsection{Soil Moisture Content (oven-drying method)}

The results showed different moisture contents between Deir El-Ghannam and Deir El-Banat soils (Table 1).

Table 1 Soil moisture content's results for Deir El-Ghannam and Deir El-Banat

\begin{tabular}{|c|c|c|c|c|c|c|}
\cline { 2 - 7 } \multicolumn{1}{c|}{} & \multicolumn{2}{c|}{ Deir El-Ghannam soil } & \multicolumn{3}{c|}{ Deir El-Banat soil } \\
\hline Samples No & 1 & 2 & 3 & 4 & 5 & 6 \\
\hline Container weight (gm) & 24.2 & 24.2 & 24.2 & 24.2 & 24.2 & 24.2 \\
\hline Container + wet soil (gm) & 55.6 & 54.8 & 55.3 & 55.4 & 55.1 & 54.2 \\
\hline Container + dry soil (gm) & 53.2 & 52.3 & 52.4 & 54.6 & 54.2 & 53.1 \\
\hline Dry soil (gm) & 29 & 28.1 & 28.2 & 3.4 & 30 & 28.9 \\
\hline Moisture content (\%) & $28.80 \%$ & $8.90 \%$ & $10.28 \%$ & $2.63 \%$ & $3.00 \%$ & $3.81 \%$ \\
\hline
\end{tabular}

\section{Discussion}

Deir El-Ghannam glass samples suffer from different deterioration phenomena, such as "hydrogen glass and Corrosion layers which look like gel layers, where it causes and increases the degree of glass dulling. ${ }^{11}$ Hydrogen glass contains to ion exchange's reaction between the glass surface and water. ${ }^{12} \& 13$ In addition, iridescence (play of colours) appears clearly on the surface of Deir El-Ghannam glass Sample B in a thick

\footnotetext{
${ }^{11}$ Pollard and Heron, "Archaeological chemistry" p 11-25

${ }^{12}$ Ryan et al., "Glass Deterioration”, pp.839-844

${ }^{13}$ Bates et al., "Experimental Hydration Studies", p. 123
} 
layer when light is reflected. This phenomenon expresses the high dangers rate for damaged glass. ${ }^{14}$

Glass corrosion for Samples A and B can be classified according to the corrosion ratio to corrosion with non-noble or malignant patina heterogeneous, layer-corrosion. ${ }^{15}$ SEM confirmed the appearance of glass corrosion through its distinctive shape which looks like a beehive. ${ }^{16}$

Deir El-Banat glass samples were in a good condition containing, just dirty layers, soil deposits, and salt crystals in addition to air bubbles which happened during the manufacturing process. ${ }^{17}$ There were brown spots inside the glass of "Sample D" due to iron oxide being used in the manufacturing process. ${ }^{18}$

All glass samples in Deir El-Ghannam and Deir El-Banat can be classified as (Soda-LimeSilica) glass, the type of ancient glass popular for more than three thousand years. ${ }^{19 \& 20}$ This composition reveals that the main raw materials from which these raw glass fragments were, sand as a source of silica, natron as a source of alkali soda and finally lime as a source of calcium. ${ }^{21}$

There was a high percentage of silica in the "corroded glass" samples of Deir El-Ghannam due to the glass component solution and deposition of silicon ions on the surface in the soil (glass corrosion layers). In addition to the low percentage of alkaline soda and potash as a result of the same reason which came from the effect of burial environment. ${ }^{22}$

The low content of potash and magnesia indicates that this is natron-based glass. ${ }^{23}$

There was chlorine in all samples as the burial environment consisted of halite $(\mathrm{NaCl}){ }^{24}$ The amount of sulphur oxides and chlorine in the glass samples of Deir El-Banat is due to natron, which contains thernadite $\left(\mathrm{Na}_{2} \mathrm{SO}_{4}\right)$ and halite $(\mathrm{NaCl}) .{ }^{25}$ Iron oxide is an impurity associated with sand, almost exclusively responsible for colouring glass a yellowish light green, the same colour than the Samples C and D. ${ }^{26} \& 27$

EDX analysis for Deir El-Ghannam soil revealed that the soil is a wet and sandy one, rich in lime, alumina, and iron oxide. In addition, there is an increasing amount of moisture content which causes the glass corrosion. ${ }^{28 \& 29}$

${ }^{14}$ Davison, "Caring for antiquities", p 48-52

15 Abd-Allah, "Study of the effective factor on deterioration of buried glass" pp. 153-154

${ }^{16}$ Hamad, "Study of factors affecting deterioration of archaeological glass", pp. 140-143

${ }^{17}$ Dawi, "Restoration and conservation of archaeological glass in Egypt", pp. 93-101

${ }^{18}$ Hamad, "Restoration and conservation of a model of archaeological glass", pp.51-58

${ }^{19}$ Tite et al., "The composition", pp. 1284-1292

${ }^{20}$ Degryse et al., "A geochemical study of Roman to early Byzantine Glass", pp. 287-299

${ }^{21}$ Abd-Allah, "Chemical characterisation", pp. 1866-1874

${ }^{22}$ Abd-Allah, "Study of the effective factor", pp. 98-105

${ }^{23}$ Silvestri et al., "The colourless glass of Julia Felix", pp.331-341

${ }^{24}$ Hamad, "Study of factors affecting deterioration of archaeological glass", p.143

${ }^{25}$ Abd-Allah, "Devitrification behavior of corroded", pp. 39-49

${ }^{26}$ Jackson, "Making colourless glass", PP. 763-780

${ }^{27}$ Hamad et al., "Conservation and protection"

${ }^{28}$ Seas., "A conservation manual for the field archaeologist", PP. 45-64

- 234 - The Deterioration Resulting from Burial Environment on Archaeological Glass 
On the other hand, Deir El-Banat soil classified as dry and sandy soil, according to its high percentage of silica and low moisture content, which matches the good level of preservation for its archaeological glass. ${ }^{30}$

\section{Methodology plan to treat the deterioration aspects}

Using Calcium acetate $\left(\mathrm{CH}_{3} \mathrm{COO}\right)_{2} \mathrm{Ca}$ and Sodium acetate $\left(\mathrm{CH}_{3} \mathrm{COO}\right) \mathrm{Na}$ as a substitute for Calcium and Sodium ions, in addition to Ethyl silicate to consolidate corroded glass. ${ }^{31}$

Dirty layers and soil deposits should be removed carefully by mechanical wet cleaning with distilled water. ${ }^{32}$ It is necessary to use the Japanese tissue paper moistened with distilled water to extract soluble salts. After that, it is possible to strengthen and isolate the archaeological weak glass using paraloid B72 dissolved in acetone $3 \%+$ ethyl silicate dissolved in $5 \%$ alcohol. $^{33}$

\section{CONCLUSIONS}

Deterioration components as a result of the chosen burial environment are glass corrosion layers differ in their thickness and colours, Different kinds of salts "Chloride and Sulphate", Dirty layers, Soil deposits, and Cracks.

Fayoum excavations held in Deir El-Ghannam and Deir El-Banat were made in sandy soil rich in salts and iron oxides. Deterioration aspects which result of being in a burial environment, were different in Deir El-Ghannam and in Deir El-Banat, according to soil chemical composition, and soil moisture content. Indeed, the latter is higher in Deir ElGhannam than in Deir El-Banat.

The archaeological glass from Deir El-Ghannam suffered from the high moisture content, which caused over time corrosion layers on the surface of the glass. It brought salts inside the glass layers and induced crystallisation of the salts after the excavation, which is not seen in Deir El-Banat samples.

\footnotetext{
${ }^{29}$ Shelby., "Introduction to glass science", PP. 18-39

${ }^{30}$ Plenderleith et al., "Results from burial experiments", PP.97-108

${ }^{31}$ Abd-Allah, "Study of the effective factor", P.195

${ }^{32}$ Ling, "Conservation of Hellenistic vessel glass"

${ }^{33}$ Hasan et al., "An experimental study”, pp. 48-53
} 


\section{REFERENCES}

Abd-Allah (R) "Chemical characterisation and manufacturing technology of late Roman to early Byzantine glass from Beit Ras/Capitolias, Northern Jordan" Journal of archaeological science 37, (2010), pp1866-1874.

Abd-Allah (R) "Devitrification behavior of corroded: four case studies" Mediterranean Archaeology and Archaeometry 7, (2007), pp39-49.

Abd-Allah (R) "Study of the effective factor on deterioration of buried glass objects and its recent techniques of treatment and conservation, Ph.D, conservation department, faculty of archaeology, Cairo university, Egypt, (2002).

Andraos (I) "Coptic History" (1994), p 59.

Bates (J), Abrajano (T), Ebert (W), Mazer (J) "Experimental Hydration Studies of Natural and Synthetic Glasses" Volume 123 (Symposium L - Materials Issues in Art and Archaeology. USA, (1988) PP123-237.

Cronyn (J) "The Elements of Archaeological Conservation", London. (2004)

Dain-Owens (A), Kibblewhite (M), Hann (M), Godwin (R)"The risk of harm to archaeological artefacts in soil from dynamic subsurface pressures generated by agricultural operations: experimental studies" Archaeometry 55 (6), (2013), pp1175-1186.

Davison (S) "Caring for antiquities (glass and ceramics)" London, (1992).

Dawi (Salwa) "Restoration and conservation of archaeological glass in Egypt" Ph.D, conservation department, faculty of archaeology, Cairo university, Egypt, (1995).

Degryse (P), Schneider (J), Poblome (J), Waelkens (M), Haack (U), Muchez (P) "A geochemical study of Roman to early Byzantine Glass from Sagalassos, South-west Turkey" Journal of Archaeological Science, 23,( 2005) pp287-299

Hamad (Rasha) "Restoration and conservation of a model of archaeological glass objects used for medical purposes. museum of Islamic art in Cairo (Applied Study)" SHEDET (Annual Peer-Reviewed Journal Issued By The Faculty Of Archaeology, Fayoum University), 1 (2014) pp 51-58.

Hamad (Rasha) "Study of factors affecting deterioration of archaeological glass objects used for medical purposes and methods of treatment and conservation (Applied on some selected objects)", Ph.D, conservation department, faculty of archaeology, Cairo university, Egypt, (2014).

- $\quad$ Hamad (Rasha), Nagwa (S), Hamdy (A), Mohamed (M) "Conservation and protection of the Damaged Archaeological Glass by the Explosion "A case study" Journal of the Center for Mediterranean Civilizations Annual Peer-Reviewed Journal Issued By The Faculty Of Art, Sohag University), 2 (2018) pp 28-39.

HASAN (Dalia), DAWI (Salwa), Rifai (M) "An experimental study for the evaluation of materials and methods used in the treatment of tin amalgam mirrors" SHEDET(Annual Peer-Reviewed Journal Issued By The Faculty Of Archaeology, Fayoum university), 2 (2015) pp 40-53

Huisman (D), Pols (S), Joosten (I), van (O), Smit (A),'Degradation processes in colorless Roman glass: cases from the Bocholtz burial" Journal of Archaeological Science 35 (2), (2008), pp398-411

Jackson (C) "Making colourless glass in the roman period" Archaeomerty 47 (4), (2005), pp.763-780.

Jackson (C), Greenfield (D), Howie (L)"An assessment of compositional and morphological changes in model archaeological glasses in an acid burial matrix. Archaeometry 54 (3), (2012), pp489-507.

Ling (D) "Conservation of Hellenistic vessel glass at the british museum", London, (2001)

Mark (k), Gergely (T), Tamas (H) "Predicting the preservation of cultural artefacts and buried materials in soil" Science of The Total Environment, Vol 529, (2015),PP249-263

Melcher (M), Wiesinger (R), Schreiner (M) "Degradation of glass artifacts: application of modern surface analytical techniques". Accounts Chemistry Research 43 (6), (2010), pp916-926.

- 236 - The Deterioration Resulting from Burial Environment on Archaeological Glass 
Plenderlieth $(\mathrm{H})$, Warner (A) "The conservation of antiques and works of art" Oxford University press, London, (1971).

Pollard (A), Heron (C) "Archaeological chemistry, Research Science Society, Cambridge, U.K., (1996).

Roemich (H), Gerlach (S), Mottner (P), Mees (F), Jacobs (P), Van (D), Doménech (C) "Results from burial experiments with simulated medieval glasses" Material Research Society Symposium 757, (2003) pp97-108

Roemich (H), Bellendorf (P), Gerlach (S), Mottner (P), lópez (E), wittstadt (k) "Archaeological Glass: The Surface and Beyond" Interim Meeting of the ICOM-CC Working Group October 3-6, Corning, New York, U.S.A. (2010) pp 137-149

Ryan, (J), McPhail (D), Rogers (P), Oakley (V) "Glass Deterioration in the Museum Environment: A Study of the Mechanisms of Decay Using Secondary Ion Mass Spectrometry" ICOM Committee for Conservation, 11th Triennial Meeting, Edinburgh, Scotland Preprints, London, (1996), pp839-844

Seas (C) "A conservation manual for the field archaeologist" Vol.4, USA, (1994).

Shelby (J) "Introduction to glass science and technology" Research Science Society, Cambridge, U.K,, (1997)

Silvestri (A), Molin (G) "The colourless glass of Julia Felix" Journal of Archaeological Science 35, (2008), pp331-341.

Tite (M), Shortland (A), Maniatis (Y), Kavoussanaki (D) Harris (S) " The composition of the sod-rich and mixed alkali plant ashes used in the production of glass" Journal of Archaeological Science 33, (2006), pp1284-1292.

Van (G), "Weathered Archaeological Glass," Corning Museum of Glass, http://www.cmog.org/article/weathered-archaeological-glass, last accessed 15 April 2018. 